\title{
PERAN PENYALURAN DANA PIHAK KETIGA BMT MUDA JATIM PADA PENINGKATAN KESEJAHTERRAAN PELAKU UMKM PERSPEKTIF MAQASHID SYARIAH ${ }^{1}$
}

\author{
Puput Aristina \\ Departemen Ekonomi Syariah-Fakultas Ekonomi dan Bisnis-Universitas Airlangga \\ Email : putieev@gmail.com \\ Tika Widiastuti \\ Departemen Ekonomi Syariah-Fakultas Ekonomi dan Bisnis-Universitas Airlangga \\ Email : widasus@yahoo.com
}

\begin{abstract}
ABTRACT:
Baitul Mal Wat Tamwil is an institution of Islamic micro finance which has a role and function to improve the economics potential and ability of members particularly and community commonly, to improve economic welfare. This research aims to find out the role of financing fund which is given by BMT to the prosperity of SME using perspective of maqasid shariah. The approach used is qualitative approach with case study method. Technique of gathering data uses direct interview to related informants. The result of this research show that BMT MUDA Jatim has played a role improving the properity of SME who has received financing funds by using perspective of maqasid shariah through any program Islamic finance.
\end{abstract}

Keywords: Baitul Mal Wat Tamwil, Financing Fund, Prosperity, SME, Maqasid shariah.

\section{PENDAHULUAN}

Indonesia selalu mengalami

perkembangan ekonomi dari waktu ke waktu. Sejarah mencatat, keberhasilan pemerintah dalam membangun ekonomi pro-rakyat terjadi pada masa orde baru dengan program rencana pembangunan lima tahun (repelita) yang didukung oleh program lain berjangka pendek, menengah ataupun panjang yang terbukti cukup mampu menggeliatkan kembali perekonomian negara terutama sektor usaha kecil menengah. (Mubyarto, 1995:2)

Kondisi tersebut seharusnya mampu bertahan hingga penghujung tahun 90-an. Pada tahun tersebut terjadi krisis global, populer dengan istilah "krisis moneter" yang berdampak terhadap perekonomian Indonesia dimulai dengan menurunnya nilai tukar rupiah, tingginya harga-harga barang, PHK dimana-mana dan sebagainya. Pada masa itu, kondisi perekonomian yang buruk diperparah dengan kondisi politik yang tidak stabil sehingga berdampak terhadap kondisi sosial.

Sektor Usaha Mikro, Kecil dan Menengah (UMKM) memainkan suatu peran yang sangat penting di dalam pembangunan dan pertumbuhan ekonomi baik di negara-negara maju maupun di negara-negara berkembang. Menurut Tambunan (2009:1) di negara berkembang UMKM berperan penting, khususnya dari perspektif kesempatan kerja dan sumber pendapatan bagi kelompok miskin, distribusi pendapatan

\footnotetext{
1 Jurnal ini merupakan bagian dari skripsi yang ditulis oleh Puput Aristina, NIM: 041211431022 , yang diuji pada 15 April 2019.
} 
Aristina, et al/Jurnal Ekonomi Syariah Teori dan Terapan Vol. 6 No. 11 November 2019: 2198-2215; PERAN PENYALURAN DANA PIHAK KETIGA BMT MUDA JATIM PADA PENINGKATAN KESEJAHTERRAAN PELAKU UMKM PERSPEKTIF MAQASHID SYARIAH

dan pengurangan kemiskinan, serta pembangunan ekonomi pedesaan.

UMKM memiliki potensi yang besar untuk mendukung peningkatan produktivitas penyediaan lapangan kerja yang lebih luas dan peningkatan pendapatan bagi masyarakat miskin. Dalam perkembangannya, UMKM menghadapi berbagai macam persoalan yang berat karena adanya persaingan ketat, apalagi dengan masuknya produkproduk luar negeri. (Hamid dan Susilo, 2011:46)

karakteristik yang paling melekat pada sebagian besar UMKM antara lain : 1) Rendahnya kualitas Sumber Daya Manusia (SDM) yang bekerja pada sector UMKM; 2) Rendahnya produktifitas tenaga kerja yang berimbas pada rendahnya gaji dan upah; 3) Kualitas barang yang dihasilkan relatif rendah; 4) Mempekerjakan tenaga kerja wanita lebih besar daripada pria; 5) Lemahnya struktur permodalan dan kurangnya akses untuk menguatkan struktur modal tersebut; 6) Kurangnya inovasi dan adopsi teknologiteknologi baru serta; 7) Kurangnya akses pemasaran ke pasar yang potensial. Oleh karena itu, untuk mengembangkan dan memberdayakan UMKM tersebut, diperlukan sebuah lembaga keuangan yang sesuai dengan kebutuhan dan kondisi pelaku ekonomi rakyat itu sendiri.

April 2018 tercatat telah terdapat 13 Bank Umum Syariah dan 21 Unit Usaha Syariah. Ekonomi Islam memiliki tujuan utama untuk mewujudkan tingkat pertumbuhan ekonomi jangka panjang dan memaksimalkan kesejahteraan manusia (falah). Sudarsono (2007:5) mengartikan falah sebagai terpenuhinya semua kebutuhan individu masyarakat dengan tidak mengabaikan keseimbangan makro ekonomi (kepenyingan sosial), keseimbangan ekologi, serta tetap memperhatikan nilainilai agama, jiwa, intelektual, keluarga dan materi.

Pedagang seharusnya bisa menjadikan isi dari Pasal 1 Ayat 8 UU No. 7 Tahun 2014 ini sebagai sebuah pedoman agar tidak melakukan praktek perdagangan yang bertentangan dengan aturan hukum yang ada di Indonesia. Pedagang harus mampu dan mau berdagang dengan cara yang halal dan thoyib. Hal ini sesuai dengan firman Allah SWT dalam Al-Qur'an surat An-Nisa' ayat 29 sebagai berikut:

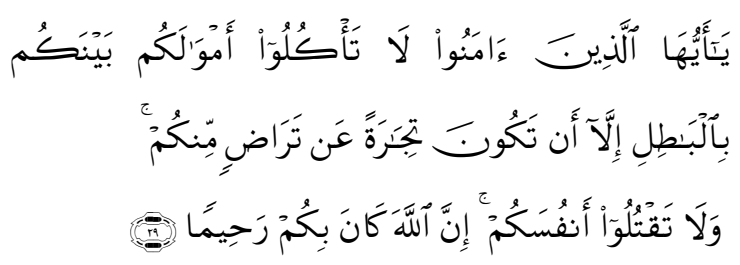

Yā 'Ayyuhā Al-Ladhinna 'Āmanū Lā

Ta'kulū'Amwālakum Baynakum Bil-Bāțili

'Illā 'AnTakūnaTijāratan 'An Tarāđin Minkum WaLāTaqtulū 'Anfusakum 'Inna Allāha Kāna Bikum Rahīmāan

Artinya: "Hai orang-orang yang beriman, janganlah kamu saling memakan harta sesamamu dengan jalan yang batil, kecuali dengan jalan perniagaan yang berlaku dengan suka sama suka di antara kamu. Dan janganlah kamu membunuh 
Aristina, et al/Jurnal Ekonomi Syariah Teori dan Terapan Vol. 6 No. 11 November 2019: 2198-2215; PERAN PENYALURAN DANA PIHAK KETIGA BMT MUDA JATIM PADA PENINGKATAN KESEJAHTERRAAN PELAKU UMKM PERSPEKTIF MAQASHID SYARIAH

dirimu; sesungguhnya Allah adalah Maha Penyayang kepadamu."

Ayat di atas menjadi pedoman bagi manusia dalam berniaga agar menggunakan cara yang baik dan halal. Selain dalam Alquran, tentang perdagangan terdapat hadist yang menjelaskan bahwa Allah tidak akan mengajak sesorang berbicara, tidak dipandang, tidak disucikan dan mereka mendapatkan siksa yang pedih apabila menipu dalam perniagaan. Seperti yang diriwayatkan dalam Hadist riwayat Abu Hurairah.

$\begin{array}{rlr}\text { Indonesia memiliki beberapa } & \text { brovinsi yang unggul di sektor }\end{array}$
perdagangan. Salah satu provinsi yang potensial untuk dikembangkan perdagangannya adalah Jawa Timur.Jumlah Usaha Kecil, Mikro, dan Menengah (UMKM) di Jawa Timur, berdasarkan survey yang dilakukan oleh Badan Pusat Statistik (BPS) Provinsi Jawa Timur hingga akhir tahun 2018 mencapai 6,8 juta UMKM. Angka tersebut menunjukkan besarnya potensi perdagangan di provinsi Jawa Timur yang jika bisa dikelola dengan baik akan mampu meningkatkan kesejahteraan para pelaku UMKM tersebut.

Lebih dari 7000 produk UKM dan UMKM Jawa Timur sudah mendahului bersaing dan bertarung di pasar ekspor ASEAN. Mengutip data Produk Domestik Regional Bruto Pemprov Jatim, perdagangan dalam negeri antar provinsi Jawa Timur pada semester 1/2015 mencapai Rp 230,55 triliun. Sementara impor antar provinsi hanya Rp 173,96 triliun. Hal ini menyebabkan nilai net ekspor perdagangan antar provinsi Jawa Timur surplus Rp56,59 triliun. (www.bi.go.id) Baitul Mal Wat Tamwil Mandiri Ukhuwah Persada Jawa Timur (BMT MUDA JATIM) adalah koperasi yang berbasis syariah dengan sosial pembiayaan non riba yang didirikan dengan komitmen penuh untuk menumbuh kembangkan UMKM (Usaha Mikro, Kecil dan Menengah) yang sesuai dengan amanat UUD 1945 Pasal 33 Ayat 1 yang berisi "perekonomian disusun sebagai usaha bersama berdasar asas kekeluargaan". BMT MUDA JATIM berdiri pada tanggal 7 Januari 2012 berdasarkan Badan Hukum No. PT2/10/09.01/01/V/2012 dengan Surat ljin Usaha Simpan Pinjam No. PT2/100/09/.01/01/V/2012 yang bertempat di Jalan Kedinding Lor Gang Tanjung Nomor 49, Surabaya, Jawa Timur. BMT MUDA JATIM memiliki visi untuk menjadi BMT terkemuka, profesional dan dapat memberikan kemaslahatan bagi masyarakat Kota Surabaya pada khususnya dan Jawa Timur pada umumnya. Adapun misi dari BMT MUDA JATIM yaitu (1) Memberikan pelayanan jasa koperasi berbasis syariah, profesional, amanah dan akuntabel, Memberdayakan ekonomi kerakyatan yang dapat memberikan kemaslahatan bagi umat, (3) Meningkatkan kualitas pegawai yang profesional dan mengerti sepenuhnya aspek-aspek BMT, 
Aristina, et al/Jurnal Ekonomi Syariah Teori dan Terapan Vol. 6 No. 11 November 2019: 2198-2215; PERAN PENYALURAN DANA PIHAK KETIGA BMT MUDA JATIM PADA PENINGKATAN KESEJAHTERRAAN PELAKU UMKM PERSPEKTIF MAQASHID SYARIAH

Memberdayakan jaringan mahasiswa Muslim di Kota Surabaya pada khususnya dan Indonesia pada umumnya, (5) Meningkatkan kinerja BMT dengan sistem yang berbasis teknologi informasi, dan (6) Menjunjung konsisten dalam mengaplikasikan prinsip-prinsip syariah di operasional BMT.

Terbentuknya BMT MUDA JATIM adalah langkah solusif sebagai bentuk kepedulian kepada umat, sekaligus lembaga yang mengolah dana ZISWAF untuk pemberdayaan ekonomi. Optimalisasi peran BMT MUDA JATIM dalam menjalankan aktivitas tersebut sesuai dengan aturan syari'at dan tidak bertentangan dengan peraturan perundang-undangan Negara Indonesia. BMT MUDA JATIM juga dituntut untuk mengoperasikan kegiatan-kegiatan secara efektif dan efisien untuk menjaga kepercayaan suatu amanah dari anggota-anggotanya.

Sesuai dengan misinya, BMT MUDA JATIM dalam Baitul Tamwil berperan sebagai jembatan antara orang-orang yang memiliki kelebihan dana dengan orang yang membutuhkan dana. BMT MUDA JATIM juga membantu bank dalam menjalankan fungsinya sebagai intermediasi, yaitu melalui program linkage, untuk membantu program pembiayaan UMKM yang sulit mendapatkan pembiayaan dari bank karena persyaratan yang kurang terpenuhi. Program linkage adalah program yang bersifat kemitraan, yaitu bank syariah memberikan pembiayaan ke sektor riil secara tidak langsung disalurkan melalui perusahaan mitranya, seperti BPRS (Bank Pengkreditan Rakyat Syariah) KJKS dan BMT dan lain-lain (www.kompasiana.com).

Hingga saat ini, BMT MUDA masih terhitung baru, yaitu baru berdiri selama enam tahun. berdirinya BMT tersebut yang baru berumur enam tahun, dikhawatirkan adanya kemungkinan penyusunan sistem perencanaan yang belum teratur atau tertata rapi. Di samping itu BMT MUDA harus dapat mengatur penyaluran dana dengan baik untuk dapat menyeimbangkan perannya tersebut, agar tujuan dari targetnya dapat tercapai sehingga BMT MUDA mampu bersaing dalam persaingan bisnis.

\section{LANDASAN TEORI}

\section{Pengertian Peran}

Istilah peran dalam "Kamus Besar Bahasa Indonesia" mempunyai arti pemain sandiwara (film), tukang lawak pada permainan makyong, perangkat tingkah yang diharapkan dimiliki oleh orang yang berkedudukan di masyarakat. Menurut Abu Ahmadi (1982), peran adalah suatu kompleks pengharapan manusia terhadap caranya individu harus bersikap dan berbuat dalam situasi tertentu yang berdasarkan status dan fungsi sosialnya.

Pengertian peran menurut Soerjono Soekanto (2009:213), yaitu peran merupakan aspek dinamis kedudukan (status), apabila seseorang melaksanakan 
Aristina, et al/Jurnal Ekonomi Syariah Teori dan Terapan Vol. 6 No. 11 November 2019: 2198-2215; PERAN PENYALURAN DANA PIHAK KETIGA BMT MUDA JATIM PADA PENINGKATAN KESEJAHTERRAAN PELAKU UMKM PERSPEKTIF MAQASHID SYARIAH

hak dan kewajibannya sesuai dengan kedudukannya, maka ia menjalankan suatu peranan. Pendapat lain tentang peran yang telah ditetapkan sebelumnya disebut sebagai peranan normatif. Sebagai peran normatif dalam hubungannya dengan tugas dan kewajiban dinas perhubungan dalam penegakan hukum mempunyai arti penegakan hukum secara total enforcement, yaitu penegakan hukum secara penuh. Sedangkan peran ideal, dapat diterjemahkan sebagai peran yang diharapkan dilakukan oleh pemegang peranan tersebut. Misalnya dinas perhubungan sebagai suatu organisasi formal tertentu diharapkan berfungsi dalam penegakan hukum dapat bertindak sebagai pengayom bagi masyarakat dalam rangka mewujudkan ketertiban, keamanan yang mempunyai tujuan akhir kesejahteraan masyarakat, artinya peranan yang nyata. Hakekatnya peran juga dapat dirumuskan sebagai suatu rangkaian perilaku tertentu yang ditimbulkan oleh suatu jabatan tertentu. Kepribadian seseorang juga mempengaruhi bagaimana peran itu harus dijalankan. Peran yang dimainkan hakekatnya tidak ada perbedaan, baik yang dimainkan atau diperankan pimpinan tingkat atas, menengah maupun bawah akan mempunyai peran yang sama. Peran merupakan tindakan atau perilaku yang dilakukan oleh seseorang yang menempati suatu posisi di dalam status sosial, Soerjono Soekanto
(2002:243), syarat-syarat peran mencangkup tiga hal, yaitu:

1. Peran meliputi norma-norma yang dihubungkan dengan posisi atau tempat seseorang dalam masyarakat, peranan dalam arti ini merupakan rangkaian peraturan-peraturan yang membimbing seseorang dalam kehidupan kemasyarakatan.

2. Peran adalah suatu konsep perilaku apa yang dapat dilaksanakan oleh individu-individu dalam masyarakat sebagai organisasi.

3. Peran juga dapat dikatakan sebagai perilaku individu, yang penting bagi struktur sosial masyarakat. (Soejono Soekanto, 1982:238)

\section{Sejarah dan Pengertian Baitul Mal Wat Tamwil}

Baitul Mal pertama kali dirumuskan dan didirikan oleh Rasulullah SAW dengan sangat sederhana. Baitul Mal lebih mempunyai pengertian sebagai pihak (aljihat) yang menangani setiap harta benda kaum muslimin, baik berupa pendapatan maupun pengeluaran. Hal tersebut dibuktikan dengan riwayatriwayat yang menyebutkan pendelegasian tugas Baitul Mal oleh Rasulullah SAW kepada beberapa orang sahabat tertentu, seperti tugas pencatatan, tugas penghimpunan zakat hasil pertanian, tugas pemeliharaan zakat hasil ternak, dan juga pendistribusian. Hal itu menjadi landasan yang kuat bagi Baitul Mal sudah ada sejak zaman Rasulullah SAW sekalipun belum dalam 
Aristina, et al/Jurnal Ekonomi Syariah Teori dan Terapan Vol. 6 No. 11 November 2019: 2198-2215; PERAN PENYALURAN DANA PIHAK KETIGA BMT MUDA JATIM PADA PENINGKATAN KESEJAHTERRAAN PELAKU UMKM PERSPEKTIF MAQASHID SYARIAH

bentuk institusi yang baku. Selanjutnya, dimasa pemerintahan Abu Bakar tidak terlalu ada perubahan yang besar berkaitan dengan Baitul Mal. (Qadim, 1983:25)

\section{Ciri-ciri Baitul Mal Wat Tamwil}

Secara umum BMT mempunyai ciriciri sebagai berikut:

1. Merupakan lembaga ekonomi bukan bank yang dapat dijangkau dan mampu menjangkau nasabah kecil atau mikro yang beroprasi secara syariah dengan potensi jaminan dari dalam atau sekitar lingkungannya sendiri.

2. Merupakan gabungan dari kegiatan Baitul Tamwil dan Baitul Maal.

3. BMT berusaha untuk mengumpulkan dana dan anggota dan menyalurkan kepada anggota untuk modal usaha produktif.

4. Baitul maal menerima zakat, infaq, shodaqoh dan menyalurkan kepada asnafnya menurut ketentuan syariah dengan perkiraan pemanfaatan yang paling produktif dan paling bermanfaat.

5. Berorientasi bisnis, mencari laba bersama, dan meningkatkan pemanfaatan yang paling produktif dan paling bermanfaat.

6. Ditumbuhkan dari bawah berlandaskan peran serta masyarakat disekitarnya.

7. Milik bersama masyarakat bawah dan masyarakat di sekitar BMT bukan milik perseorangan atau orang di luar masyarakat.

Sedangkan secara khusus sebagaimana dijelaskan Ridwan (2004:132), BMT memiliki ciri-ciri sebagai berikut:

1. Staf dan karyawan BMT bertindak aktifproaktif, tidak menunggu tetapi menjemput bola, bahkan merebut bola, baik untuk menghimpun dana anggota maupun untuk pembiayaan.

2. Kantor dibuka dalam waktu tertentu yang ditetapkan sesuai kebutuhan pasar.

3. BMT mengadakan pendampingan usaha anggota.

\section{Fungsi Baitul Mal Wat Tamwil}

Fungsi dari aktifitas yang dijalankan oleh BMT sebagai upaya kongkrit pencapaian tujuan yang diharapkan yang telah dijelaskan di atas. Ridwan (2004:131) menjelaskan Baitul Mal Wat Tamwil berfungsi sebagai :

1. Pengembangan potensi ekonomi masyarakat dan anggotanya untuk mencapai kesejahteraan.

2. Peningkatan kualitas SDM anggota menjadi lebih profesional dan islami.

3. Sebagai perantara keuangan baik fungsi Maal maupun Tamwil untuk usaha produktif.

\section{Peran Baitul Mal Wat Tamwil}

Dalam rangka mencapai tujuannya, BMT memiliki peran sebagai berikut:

1. Mengidentifikasi, memobilisasi, mendorong, dan mengembangkan 
potensi ekonomi anggota, kelompok muamalat, dan daerah kerjanya.

2. Meningkatkan kualitas SDI (Sumber Daya Insani) anggota menjadi lebih profesional dan islami sehingga semakin kuat dalam menghadapi persaingan global.

3. Menggalang dan memobilisasi potensi masyarakat dalam rangka meningkatkan kesejahteraan anggota.

4. Menjadi perantara keuangan (financial intermediary) di antaranya sebagai shohibul maal dengan duafa sebagai mudharib, terutama untu dana-dana sosial seperti zakat, infaq, sedekah, wakaf, dan hibah.

\section{Prinsip Operasional Baitul Mal Wat Tamwil}

Prinsip-prinsip operasional Baitul Mal Wat Tamwil tidak jauh berbeda dengan yang digunakan oleh Bank Islam. Ridwan (2004:29), menjelaskan sedikitnya tiga prinsip operasional Baitul Mal Wat Tamwil sebagai berikut :

1. Prinsip Bagi Hasil

2. Prinsip Jual Beli dengan Keuntungan (Mark Up)

3. Prinsip Non-Profit

\section{Produk-Produk Baitul Mal Wat Tamwil}

Produk-produk yang dihasilkan oleh BMT sangat banyak. Produk-produk yang dihasilkan tersebut berupa produk penghimpunan maupun produk penyaluran. Menurut Muhammad (2006:32) produk inti dari BMT terdiri atas produk penghimpunan dana (funding) dan produk penyaluran dana (lending).

1. Produk Penghimpun Dana (Funding)

\section{Produk Penyaluran Dana (Lending)}

\section{Penyaluran Dana}

Pengertian penyaluran dana adalah menjual kembali dana yang diperoleh dari penghimpunan dana dalam bentuk simpanan. Dalam penyaluran dana ini pihak bank harus memiliki strategi yang mumpuni untuk menyalurkan dananya ke masyarakat melalui alokasi yang strategis sehingga keuntungan yang didapat bisa dimaksimalkan.

Tujuan bank dari pengalokasian dana adalah memperoleh keuntungan semaksimal mungkin. Dalam mengalokasikan dana, pihak perbankan membaginya ke dalam prosentase tertentu sesuai dengan kondisi yang terjadi di dalam perekonomian pada saat sekarang ini misalnya untuk bidang pertanian diberikan $20 \%$ sedangkan untuk bidang industsri $40 \%$ Sumber (Carlezpekuncen.blogspot.com/2017/04/ produk-penyaluran-dana.)

\section{Produk Penyaluran Dana}

Jenis-jenis produk penyaluran dana adalah:

1. Pembiayaan Mudharabah

Menurut Antonio (2001:95), AlMudharabah adalah akad kerja sama antara dua pihak di mana pihak pertama menyediakan 100\% modal, sedangkan pihak lainnya menjadi pengelola. Keuntungan usaha secara mudharabah dibagi menurut kesepakatan yang dituangkan dalam kontrakManajemen BMT adalah 
Aristina, et al/Jurnal Ekonomi Syariah Teori dan Terapan Vol. 6 No. 11 November 2019: 2198-2215; PERAN PENYALURAN DANA PIHAK KETIGA BMT MUDA JATIM PADA PENINGKATAN KESEJAHTERRAAN PELAKU UMKM PERSPEKTIF MAQASHID SYARIAH

profesional alamiMenurut

2. Pembiayaan Musyarakah

Suwiknyo (2009:103) mendefiniskan musyarakah sebagai akad kerja sama antara dua pihak atau lebih untuk usaha tertentu di mana masing-masing pihak memberikan kontribusi dana dengan kesepakatan bahwa keuntungan dan resiko akan ditanggung bersama sesuai dengan kesepakatan dan seberapa besar kontribusi dana. Menurut Dewan Syariah Nasional MUI dan PSAK Np. 106 mendefinisikan musyarakah sebagai akad kerjasama antara dua pihak atau lebih untuk suatu usaha tertentu, di mana masing-masing pihak memberikan kontribusi dana dengan ketentuan dibagi berdasarkan kesepakatan sedangkan kerugian berdasarkan kontribusi dana.

3. Pembiayaan Murabahah

Secara bahasa, murabahah berasal dari kata Ar-Ribhu yang berarti tumbuh dan berkembang, atau murabahah juga berarti Al-Irbaah, karena salah satu dari dua orang yang bertransaksi memberikan keuntungan kepada yang lainnya (Rusyd, 1990:443).

4. Salam

Ulama Malikiyyah menyatakan salam adalah akad jual beli di mana modal (pembayaran) dilakukan secara tunai (di muka) dan obyek pesanan diserahkan kemudian dengan jangka waktu tertentu (Muhammad, 2000:5859).
5. Istisna'

Transaksi bai'al-istisna' dijelaskan Antonio (2001:113) merupakan kontrak penjualan antara pembeli dan pembuat barang dengan spesifikasi yang telah disepakati. Menurut jumhur fuqaha', bai'al-istisna' merupakan jenis khusus dari akad bai'as-salam.

6. Ijarah

Al-ijarah adalah akad pemindahan hak guna atas barang atau jasa melalui pembayaran upah sewa tanpa diikuti dengan pemindahan kepemilikan atas barang itu sendiri (sabiq, 2004:183).

7. Ijarah Muntahiyah Bi Tamlik

Menurut Sabia (2004 : 272), ljarah Muntahiyah Bi Tamlik adalah transaksi sewa dengan perjanjian untuk menjual atau menghibahkan objek sewa di akhir periode sehingga transaksi ini diakhiri dengan kepemilikan objek sewa.

\section{Konsep Kesejahteraan}

Tingkat kepuasan dan kesejahteraan adalah dua pengertian yang saling berkaitan. Tingkat kepuasan merujuk pada keadaan individu atau kelompok, sedangkan tingkat kesejahteraan mengacu kepada keadaan komunitas atau masyarakat luas. Kesejahteraan adalah kondisi agregat dari kepuasan individu-individu.

Konsep kesejahteraan menurut Nasikun (1996:78) dapat dirumuskam sebagai padanan makna dari konsep martabat manusia yang dapat dilihat dari 4 indikator, yaitu : 1. Rasa aman (security), 
Aristina, et al/Jurnal Ekonomi Syariah Teori dan Terapan Vol. 6 No. 11 November 2019: 2198-2215; PERAN PENYALURAN DANA PIHAK KETIGA BMT MUDA JATIM PADA PENINGKATAN KESEJAHTERRAAN PELAKU UMKM PERSPEKTIF MAQASHID SYARIAH

2. Kesejateraan (welfare), 3. Kebebasan (freedom), 4. Jati diri (identity).

Todaro (2003:34) mengemukakan bahwa kesejahteraan masyarakat menengah ke bawah dapat direpresentasikan dari tingkat hidup masyarakat. Tingkat hidup masyarakat ditandai dengan berkurangnya kemiskinan, tingkat kesehatan yang lebih baik, perolehan tingkat pendidikan yang lebih tinggi, dan tingkat produktivitas masyarakat.

\section{Kesehteraan dalam Perspesktif Islam}

Secara umum, agama (religion) diartikan sebagai presepsi dan keyakinan manusia terkait dengan alam semesta dan eksistensinya serta peran Tuhan terhadap alam semesta kehidupan manusia sehingga membawa kepada pola hubungan dan perilaku manusia dengan Tuhan, manusia dengan sesama manusia yang lain, dan manusia dengan alam semesta. Falah diartikan sebagai kemenangan hidup di dunia dan di akhirat baik daro aspek material maupun spiritual. Falah memiliki tiga unsur yaitu kelangsungan hidup, kebebasan berkeinginan, dan kekuatan akan harga diri. Usaha dan ikhtiar adalah sebagai upaya ibadah untuk mencapai kemenangan dunia dan akhirat sehingga setiap perkataan dan perbuatan dijalankan berdasarkan petunjuki Allah yang ada dalam Al-Qur'an. Di sinilah manusia mendapatkan kesejahteraan secara menyeluruh baik materi maupun spiritual yang bernilai jangka pendek (dunia) dan jangka panjang (akhirat).

Adapun maslahah merupakan dampak positif dari memperoleh falah, yaitu kebutuhan yang tercapai secara seimbang, di mana falah ini akan memberikan kebahagiaan, sehingga masyarakat mendapatkan maslahah. Maslahah juga dapat dinilai sebagai kemanfaatan baik material maupun nonmaterial yang menjadikan manusia pada keadaan mulia. Maslahah diungkapkan oleh Imam Asy-syatibi mencakup lima hal, yaitu agama, jiwa, intelektual, keluarga, dan material. Dengan demikian, ikhtiar yang dijalankan oleh penduduk berdasarkan pada konsep ini harus senantiasa menimbang pada pencapaian falah yang didasarkan pada unsur maslahah (Karim, 2001:6)

\section{Indikator Kesejahteraan UMKM Secara Umum}

Dalam pemenuhan kebutuhan harus dipenuhi berdasarkan tingkatannya. Kalau salah satu kebutuhan tersebut tidak dapat terpenuhi maka akan mengakibatkan masalah dalam kehidupannya. Menurut Diola (2011) ada beberapa indikator kesejahteraan pelaku UMKM. Beberapa indikator yang disebut berikut lebih banyak didasarkan pada pendekatan ilmu perdagangan dan UMKM. Beberapa indikator tersebut adalah sebagai berikut:

1. Pendapatan

2. Pendapatan dapat diartikan sebagai penerimaan atau jumlah yang 
Aristina, et al/Jurnal Ekonomi Syariah Teori dan Terapan Vol. 6 No. 11 November 2019: 2198-2215; PERAN

PENYALURAN DANA PIHAK KETIGA BMT MUDA JATIM PADA PENINGKATAN KESEJAHTERRAAN PELAKU UMKM PERSPEKTIF MAQASHID SYARIAH

didapatkan atas hasil usaha. Rumah atau Tempat Tinggal

3. Rumah adalah salah satu persyaratan pokok dalam hidup manusia selain pangan dan sandang. Rumah berfungsi sebagai tempat tinggal serta digunakan untuk berlindung dari hujan, berteduh saat siang hari, dan untuk istirahat di malam hari. Pangan dalam kehidupan sehari-hari manusia tidak dapat terlepas dari makanan. Sebab makanan merupakan syarat pokok hidup manusia selain udara.

4. Sandang. Pakaian adalah hal penting dalam kehidupan. Dengan pakaian kita dapat terhindar dari panasnya sinar matahari, melindungi dari cuaca dingin, dan menjadikan kita indah dan rapi. Pakaian juga dapat membuat kita terlihat indah di mata orang lain jika mengguanakan cara yang benar.

5. Pendidikan

6. Dalam kehidupan sehari-hari manusia memiliki kelebihan dan kemampuan yang dapat dikembangkan melalui pendidikan pengalaman. Kesehatan

7. Kesehatan adalah keadaan sehat, baik secara fisik, mental, spiritual, maupun sosial memungkinkan setiap orang untuk hidup produktif secara sosial dan ekonomis (Undang-Undang Nomor 36 Tahun 2009 tentang Kesehatan). Pengertian tersebut memberi arti yang luas tentang kesehatan.

8. Tabungan. Tabungan adalah simpanan sebagian pendapatan yang dimiliki oleh seseorang yang tidak dibelanjakan sehingga dapat digunakan sewaktu-waktu apabila diperlukan (Sudarman, 2003:9).

\section{Indikator Kesejahteraan dalam Islam}

Islam merupakan ajaran yang sangat peduli terhadap kesejahteraan sosial. Kesejahteraan sosial dalam Islam pada intinya mencakup dua hal yaitu, kesejahteraan sosial yang menyangkut jasmani dan rohani. Manifestasi kesejahteraan sosial dalam Islam adalah bahwa setiap individu dalam Islam harus memperoleh perlindungan terhadap lima hal yang biasa disebut dengan maslahah.

Menurut Al-Shatibi, maslahah dasar bagi manusia terdiri dari agama (din), jiwa (nafs), intelektual (aql), keluarga (nasl), dan material (maal) (Karim, 2001 : 5-6) kelima mas/ahah tersebut dapat dijadikan sebagai indikator kesejahteraan secara Islami karena mencakup kebutuhan pokok manusia yang harus dipenuhi agar dapat hidup sejahtera di dunia dan di akhirat. Penjelasan mengenai kelima kebutuhan dasar tersebut (agama, jiwa, intelektual, keluarga, dan material) dijelaskan sebagai berikut :

1. Agama (Al-Din)

Tadjab (1994:37) menyatakan bahwa agama berasal dari kata "a" yang berarti tidak dan "gama" yang berarti kacau, kocar-kacir. Jadi, agama artinya tidak kacau, tidak kocar-kacir, dan atau teratur. Maka, istilah agama merupakan suatu kepercayaan yang mendatangkan kesejahteraan dan 
Aristina, et al/Jurnal Ekonomi Syariah Teori dan Terapan Vol. 6 No. 11 November 2019: 2198-2215; PERAN PENYALURAN DANA PIHAK KETIGA BMT MUDA JATIM PADA PENINGKATAN KESEJAHTERRAAN PELAKU UMKM PERSPEKTIF MAQASHID SYARIAH

keselamatan hidup manusia.

2. Jiwa (Al-Nafs)

Al-Qur'an memberikan apresiasi yang sangat besar terhadap kajian yang menyangkut masalah jiwa (nafs) manusia.

3. Akal (Al-'Aql)

4. Keturunan (An-Nasl)

5. Harta (Maal)

Perintah Allah untuk menjaga harta adalah sifat dari disyariatkan zakat, infaq, dan shodaqoh.

\section{Konsep Maqashid Syariah}

Pengertian dan dasarnya secara bahasa, maqashid syariah berasal dari dua kata, yaitu maqashid dan syariah. Maqashid adalah bentuk jamak dari maqsud yang berarti kesengajaan atau tujuan, sedangkan syariah secara bahasa artinya jalan menuju sumber air, yang juga bisa diartikan jalan menuju sumber kehidupan. Dengan demikian maqasid syari'ah secara etimologis adalah tujuan menetapkan syariah. Pengertian ini dilandasi asumsi bahwa penetapan syariah memiliki tujuan tertentu oleh pembuatnya (syari'). Tujuan penetapan itu dinyakini adalah untuk kemaslahatan manusia sebagai sasaran syariah.

\section{Tujuan Maqashid Syariah}

Tujuan hukum harus ditemukan untuk mengetahui apakah suatu kasus masih relevan ditetapkan dengan ketentuan hukum yang sudah ada ketika terjadi perubahan struktur sosial. Konsep maqasid syari'ah bertujuan untuk menegakkan kemaslahatan sebagai unsur pokok tujuan hukum. Menurut Imam AsySyatibi membagi empat aspek maqasid syari'ah, yaitu sebagai berikut :

1. Tujuan awal dari Syari' menetapkan syariah yaitu kemashlahatan manusia di dunia dan akhirat.

2. Penetapan syariah sebagai sesuatu yang harus dipahami.

3. Penetapan syariah sebagai hukum taklifi yang harus dilaksanakan.

4. Penetapan syariah guna membawa manusia ke bawah lindungan hukum.

\section{METODE PENELITIAN}

\section{Pendekatan Penelitian}

Penelitian dapat dilakukan dengan pendekatan kualitatif. Pendekatan yang digunakan dalam penelitian ini adalah pendekatan kualitatif dengan metode studi kasus deskriptif. Studi kasus (case study) merupakan strategi yang cocok bila pokok pertanyaan penelitian berkenan dengan "how" atau "why", bila peneliti hanyamemiliki sedilkit peluang untuk mengontrol peristiwa-peristiwa yang akan diteliti, dan apabila peneliti terlibat langsung dalam penelitian, dan bila fokus penelitian terletak pada fenomena kontemporer (masa kini) di dalam konteks kehidupan nyata, serta terdapat proposisi di dalamnya (Yin, 2009:1).

\section{Ruang Lingkup Penelitian}

Ruang lingkup penelitian ini adalah suatu batasan penelitian yang digunakan mengingat kompleksitas realita yang dihadapi. Penelitian dalam skripsi ini dilakukan untuk menjawab rumusan 
Aristina, et al/Jurnal Ekonomi Syariah Teori dan Terapan Vol. 6 No. 11 November 2019: 2198-2215; PERAN PENYALURAN DANA PIHAK KETIGA BMT MUDA JATIM PADA PENINGKATAN KESEJAHTERRAAN PELAKU UMKM PERSPEKTIF MAQASHID SYARIAH

masalah yang ada yaitu bagaimana peran penyaluran dana Baitul Mal Wat Tamwil pada peningkatan kesejahteraan pelaku UMKM perspekstif maqashid syariah dengan ruang lingkup penelitian sebagai berikut:

1. Penelitian ini difokuskan kepada peran dan manfaat penyaluran dana yang dilakukan oleh Baitul Mal Wat Tamwil "MUDA" terhadap pelaku UMKM di kota Surabaya.

2. Membatasi penelitian dengan menggunakan data-data internal Baitul Mal Wat Tamwil "MUDA" dalam hal penyaluran dana maupun dokumentasi penelitian-penelitian sebelumnya.

Membatasi penelitian dalam mengukur tingkat kesejahteraan tingkat kesejahteraan pelaku UMKM yang mendapatkan pembiayaan dari Baitul Mal Wat Tamwil "MUDA" dengan menggunakan kelima indikator kesejahteraan maqashid syariah seperti yang telah dijelaskan di atas.

\section{Jenis dan Sumber Data}

Data yang digunakan dalam penelitian ini meliputi data primer dan data sekunder. Data primer adalah data empiris yang diperoleh secara langsung oleh peneliti dari para responden dengan menggunakan daftar pertanyaan atau wawancara sehingga memudahkan peneliti untuk menganalisis permasalahan. Data primer disebut juga data asli. Maka untuk mendapatkan data primer, peneliti harsu mengumpulkannya secara langsung.

\section{Prosedur Pengumpulan Data}

Penelitian ini membutuhkan dua sumber data yaitu data primer dan data sekunder. Dalam pengumpulan kedua data tersebut memiliki prosedur yang berbeda antara data primer dan sekunder. Data primer diperoleh melalui prosedur berikut:

1. Persiapan awal

Pada tahap ini, peneliti mengurus surat ijin penelitian skripsi secara formal pada bagian akademik Fakultas Ekonomi Bisnis Universitas Airlangga sebagai berkas pelengkap dalam melakukan penelitian di BMT MUDA Jawa Timur. Tujuan dari ijin penelitian ini adalah untuk mempermudah menggali informasi dan data yang mendalam pada BMT yang berhubungan dengan penelitian untuk dijadikan kerangka dasar penelitian.

2. Proses Memasuki Lokasi Penelitian

Pada tahap ini peneliti menemui pimpinan BMT MUDA Jawa Timur dengan membawa surat ijin penelitian.

3. Saat di Lokasi Penelitian

Pada tahap ini, peneliti menjelaskan maksud, tujuan dan ijin untuk melakukan penelitian kepada BMT MUDA Jawa Timur untuk kemudian melakukan observasi partisipasif dan wawancar secara mendalam dengan pimpinan dan beberapa pengelola untuk menggali informasi tentang situasi dan kondisi BMT MUDA Jawa Timur saat ini secara umum serta 
Aristina, et al/Jurnal Ekonomi Syariah Teori dan Terapan Vol. 6 No. 11 November 2019: 2198-2215; PERAN PENYALURAN DANA PIHAK KETIGA BMT MUDA JATIM PADA PENINGKATAN KESEJAHTERRAAN PELAKU UMKM PERSPEKTIF MAQASHID SYARIAH

menggali data yang berkaitan dengan penyaluran dana BMT, akad yang digunakan, dan peran BMT MUDA Jawa Timur dalam meningkatkan kesejahteraan pelaku UMKM di kota Surabaya. Observasi dilakukan secara terus menerus secara berkala selama beberapa hari sampai peneliti menemukan gambaran umum sebagai dasar kerangka teori penelitian dan fokus penelitian.

4. Saat Pengumpulan Data

Pada saat ini, peneliti melakukan wawancara dan observasi partisipatif langsung kepada beberapa pelaku masyarakat yang menerima dana pembiayaan dari BMT MUDA Jawa Timur. Hal ini dilakukan untuk mendapat jawaban atas rumusan masalah yang ada. Hasil dari wawancara dan observasi partisipatif dari objek penelitian didokumentasikan sendiri oleh peneliti untuk kemudian diolah dan dianalisis.

Sedangkan data sekunder yang digunakan untuk mendukung penelitian ini diperoleh melalui prosedur sebagai berikut

1. Studi kepustakaan, yaitu data-data yang diperoleh dari jurnal-jurnal skripsi terdahulu, penelitian-penelitian, makalah, buku-buku pustaka, mengikuti perkuliahan tentang Baitul Mal Wat Tamwil, dan referensi lain yang bersangkutan.
2. Data internet, melalui search engine pada situs-situs yang relevan tentang Baitul Mal Wat Tamwil.

\section{Teknik Keabsahan Data}

Penelitian keabsahan penelitian kualitatif dilakukan pada saat proses pengumpulan data. Untuk mengukur keabsahan data penelitian diperlukan teknik pemeriksaan. Pelaksanaan teknik pemeriksaan dilakukan berdasarkan beberapa kriteria tertentu. Dalam penelitian ini, untuk memeriksa keabsahan data, penulis menggunakan teknik triangulasi. Triangulasi dalam penelitian studi kasus adalah pendapatan yang dilakukan terhadap sumber yang berbeda namun masih memiliki keterkaitan satu sama lain sehingga informasi yang diperoleh akan lebih lengkap dan meyakinkan. Ada tiga teknik triangulasi dalam penelitian yaitu, triangulasi sumber, triangulasi teknik dan triangulasi waktu.

\section{Teknik Analisis Data}

Dalam penelitian ini setelah dilakukan pengumpulan data, maka data tersebut dianalisis untuk mendapatkan kesimpulan. Menurut Yin (2013: 140) bentuk teknik analisis data yang dapat digunakan dalam penelitian studi kasus adalah sebagai berikut :

1. Penjodohan Pola (Pattern Matching) Teknik analisis penjodohan pola yaitu menggunakan logika penjodohan pola. Logika seperti ini membandingkan pola yang didasarkan atas data empiris dengan 
Aristina, et al/Jurnal Ekonomi Syariah Teori dan Terapan Vol. 6 No. 11 November 2019: 2198-2215; PERAN PENYALURAN DANA PIHAK KETIGA BMT MUDA JATIM PADA PENINGKATAN KESEJAHTERRAAN PELAKU UMKM PERSPEKTIF MAQASHID SYARIAH

pola yang diprediksikan atau dengan beberapa prediksi alternatif. Jika kedua pola ini memiliki persamaan, hasilnya dapat menguatkan validitas studi kasus yang bersangkutan.

2. Pembuatan Penjelasan (Explanation Building)

Teknik analisis ini bertujuan untuk menganalisis data studi kasus dengan cara membuat suatu ekspetasi tentang kasus yang bersangkutan untuk keberlanjutan studi.

3. Analisis Deret Waktu (Time-Series Analysis)

Teknik analisis deret waktu hampir sama dengan teknik penjodohan pola. Perbedaannya terletak pada pola yang dijodohkan. Analisis deret waktu lebih menekankan pada prosedur atau kronologis suatu peristiwa (pendekatan eksperimen).

IV. HASIL DAN PEMBAHASAN

Deskripsi Hasil Penelitian

Sejarah Baitul Maal Wat Tamwil Mandiri Ukhuwah Persada Jawa Timur (BMT MUDA JATIM)

Gagasan pendirian BMT MUDA diawali dari ide salah seorang alumnus Master of Econimics International Islamics University Malaysia (IIUM), yakni Shochrul Rohamtul Ajija. Dengan mengajak beberapa kolega yang sama-sama alumni IImu Ekonomi dan Bisnis Universitas Airlangga, yakni Suhardianti Endi Akhsani (Onish) dan Yusifa Nur Aulia, akhirnya mereka bisa merumuskan pendirian sebuah BMT dengan nama Mandiri
Ukhuwah Persada atau yang disingkat dengan BMT MUDA. Semangat yang pantang surut mendorong ketiga perempuan tersebut berhasil meyakinkan para pendiri awal.

Desember 2011 menjadi bulan bersejarah bagi rintisan pendirian BMT MUDA. Pada waktu itu telah mampu terhimpun 48 pendiri BMT MUDA dengan skala Jawa Timur, yakni 20 pendiri dengan KTP Kota Surabaya, 20 pendiri dengan KTP Kabupaten atau Kota Mojokerto, dan 8 pendiri dengan KTP luar Surabaya maupun Mojokerto.

\section{Motto dan Visi Misi}

Motto dan Visi Misi BMT MUDA Jatim adalah:

1. Motto

Berdaya, mandiri, Sejahtera.

2. Visi

Menjadi BMT terkemuka, profesional dan dapat memberikan kemaslahatan bagi masyarakat kota Surabaya pada khususnya dan Jawa Timur pada umumnya.

3. Misi

Untuk mencapai visi diatas, maka misi BMT "Mandiri Ukhuwah Persada"

a. Memberikan pelayanan jasa koperasi yang berbasis syariah, profesional, amanah dan akuntabel.

b. Memberdayakan ekonomi kerakyatan yang dapat memberikan kemaslahatan bagi umat. 
c. Meningkatkan kualitas pegawai yang profesional dan mengerti sepenuhnya aspek-aspek BMT.

d. Memberdayakan jaringan mahasiswa muslim Kota Surabaya pada khusunya dan Indonesia pada umumnya.

e. Meningkatkan kinerja BMT dengan sistem yang berbasis teknologi informasi.

f. Menjunjung konsistensi dalam mengaplikasikan prinsip-prinspi syariah di operasional BMT.

\section{Produk-produk BMT MUDA JAWA TIMUR}

Produk dan layanan BMT MUDA mengutamakan prinsip syariah disertai dengan kenyamanan, keamanan, keleluasaan dan kemudahan bertransaksi. Berbagai produk BMT MUDA adalah:

1. Unit Usaha Riil yang Meliputi:

a. Unit Usaha Pulsa: melayani pembelian pulsa secara grosir dan retail.

b. Unit Usaha Catering: melayani pemesanan makanan, baik kotak maupun bungkus.

2. Unit Jasa Keuangan Syariah (UJKS), yang meliputi:

a. Simpanan
a) Tabungan umum (Rela MUDA)
b) Deposito MUDA
C) Tabungan pelajar
d) Tabungan Idul Fitri
e) Tabungan Qurban
f) Tabungan Umrah
g) Tabungan Walimah

b. Pembiayaan
a) Pembiayaan Mudharabah
b) Pembiayaan Murabahah
C) Pembiayaan Qard

c. Jasa Layanan
a) Pembelian Isi Ulang Pulsa
b) Transfer Antar Bank
C) Pembayaran PLN Listrik

d. Baitul Maal

a) Penghimpunan Zakat, Infaq, Shodaqoh, dan Wakaf (ZISWAF)

b) Penyaluran ZISWAF untuk beasiswa, sumbangan kemanusiaan, sumbangan lembaga keagamaan, dan sosial keagamaan.

Inteprestasi Setiap Indikator Kesejahteraan Inteprestasi masing-masing indikator dalam penelitian ini di jelaskan sebagai berikut:

1. Indikator Agama (Al-Din)

Dari hasil di atas, dari 6 pelakU UMKM yang menjadi informan, sebanyak 4 yang merasa mengalami peningkatan dalam indikator agama (kemampuan mengeluarkan ZIS) sedangkan 2 informan yang belum mengalami peningkatan yang signifikan karena dari waktu ke waktu mereka hanya mampu mengeluarkan zakat, infaq, maupun sedekah dengan jumlah yang relatif stabil. Sedangkan dalam pengetahuan tentang Ekonomi Islam mayoritas hanya mengetahui Ekonomi Islam dari hal-hal yang umum saja. Sedangkan hal-hal yang bersifat khusus masih menjadi sesuatu yang baru bagi 
Aristina, et al/Jurnal Ekonomi Syariah Teori dan Terapan Vol. 6 No. 11 November 2019: 2198-2215; PERAN PENYALURAN DANA PIHAK KETIGA BMT MUDA JATIM PADA PENINGKATAN KESEJAHTERRAAN PELAKU UMKM PERSPEKTIF MAQASHID SYARIAH

para informan tersebut. Indikator Akal (Al-Aql)

Dari hasil di atas, dari 6 pelaku UMKM yang menjadi informan, sebanyak 4 yang merasa mengalami peningkatan yang signifikan dalam indikator akal (pendidikan) karena mereka mampu menyekolahkan anak hingga kejenjang perkuliahan sedangkan 2 pelaku UMKM tidak mengalami peningkatan karena mereka sudah tidak ada tanggungan pendidikan karena anak mereka sudah bekerja dan berkeluarga.

2. Indikator Harta (Al-Mal)

Dari hasil di atas, dapat diketahui bahwa ada 6 pelakU UMKM yang mengalami peningkatan harta. Mulai dari sumber modal dan sumber pendapatan mereka meningkat. Informan yang mengalami peningkatan dalam indikator harta ini karena selain mereka telah menjalankan usahanya dalam waktu yang cukup lama, mereka juga sudah memiliki pelanggan tetap. Jadi, bisa dikatakan penghasilan stabil setiap harinya.

Peran Penyaluran Dana Pihak Ketiga BMT MUDA Jawa Timur Pada Peningkatan Kesejahteraan Pelaku UMKM

Sub bab ini akan menjelaskan secara deskriptif hasil wawancara terhadap semua informan. Berikut ini hasil analisis berdasarkan wawancara dengan para informan yang berjumlah 6 orang.

1. Sumber Pendapatan

Mengenai sumber pendapatan yang diperoleh dan didapatkan oleh semua informan dari hasil bekerja setiap harinya dapat dianalisis sebagai berikut

a. Semua informan diketahui hanya mengandalkan pekerjaan utamanya yaitu berdagang dan menjahit sebagai sumber pendapatan sehari-hari.

2. Implementasi Program pembiayaan Berdasarkan hasil wawancara, di peroleh informasi sebagai berikut:

a. Beberapa informan mengaku adanya peningkatan agama yaitu kemampuan untuk membayar zakat, infaq, maupun sedekah setelah mendapat pembiayaan dari BMT.

b. Dengan adanya pembiayaan ini beberapa informan mengaku pengetahuan mereka tentang Ekonomi Islam khususnya BMT semakin bertambah.

c. Beberapa informan juga mengaku bahwa dengan adanya dana pembiayaan ini dapat membantu biaya pendidikan anak mereka.

3. Perubahan Sebelum dan Sesudah Menerima Dana Pembiayaan

\section{v. SIMPULAN}

Berdasarkan analisis pembahasan sebelumnya dapat disimpulkan bahwa BMT MUDA JATIM berperan dalam meningkatkan kesejahteraan anggota melalui berbagai produk pembiayaannya. Produk-produk tersebut berupa pembiayaan dengan berbagai model 
Aristina, et al/Jurnal Ekonomi Syariah Teori dan Terapan Vol. 6 No. 11 November 2019: 2198-2215; PERAN PENYALURAN DANA PIHAK KETIGA BMT MUDA JATIM PADA PENINGKATAN KESEJAHTERRAAN PELAKU UMKM PERSPEKTIF MAQASHID SYARIAH

dan variasi yang berbeda antara produk satu dengan produk yang lainnya. Dalam hal kesejahteraan, terdapat faktor internal dan faktor eksternal yang mempengaruhi.

Faktor internal dan faktor eksternal yang mempengaruhi peningkatan kesejahteraan pelaku UMKM tersebut adalah :

1. Faktor internal yang mempengaruhi peningkatan kesejahteraan antara lain kesadaran pelaku UMKM dalam mengolah dan mengalokasikan dana yang didapat dari BMT, bersungguhsungguh dalam mengelola dan menjalankan usahanya, dan mendapat dukungan penuh dari keluarga maupun kerabat yang lain.

2. Faktor eksternal yang mempengaruhi peningkatan kesejahteraan adalah kedekatan hubungan pelaku UMKM dengan pihak BMT dalam mengevaluasi dan mengoreksi kelebihan dan kekurangan masingmasing bentuk program pembiayaannya.

\section{Saran}

1. Bagi anggota BMT, sebaiknya sebelum mengambil dana pembiayaan di BMT supaya memahami dan mengerti terlebih dahulu jenis dan akad dari masing-masing program pembiayaan agar dana yang didapatkan nanti dapat digunakan sesuai dengan kebutuhan.

2. Bagi BMT MUDA JATIM, untuk lebih meningkatkan sosialisasi terkait dengan program pembiayaan yang dimiliki kepada para anggotanya. Selain itu pendampingan, pelatihan terhadap anggota juga lebih ditingkatkan lagi.

3. Bagi peneliti selanjutnya, agar dihasilkan penelitian yang jauh lebih baik dan lebih lengkap lagi mengenai peran BMT dalam meningkatkan kesejahteraan anggotanya. Penelitian tersebut bisa dilakukan di BMT atau KJKS yang lain yang ada di Kota Surabaya atau di Kota lain yang ada di Jawa Timur.

\section{DAFTAR PUSTAKA}

Ali, Hamdani. 1986. Filsafat Pendidikan. Yogyakarta: Kota Kembang.

Andriani. 2005. Baitul Mal Wat Tamwil (Konsep dan Mekanisme di Indonesia). Bandung: Pustaka Setia Antonio, Muhammad Syafi'i. 2001 . Bank Syariah dan Teori Praktik. Jakarta: Gema Insani

DSN MUI. Produk Tabungan dan Produk Penghimpunan Dana Baitul Mal Wat Tamwil. Fatwa DSN MUI No. 02?DSN-MUI/IV/2000 tentang produk tabungan dan Baitul Mal Wat Tamwil.(Online). (www.google.com diakses pada 20 agustus 2018)

Hamid, Edy Suandi dan Sri Susilo Y. 2011. Strategi Pembangunan Usaha Mikro Kecil dan Menengah Provinsi Daerah Istimewa Yogyakarta, Jurnal

Ekonomi Pembangunan, Vol. 12 No. 1 Juni, 2011, hal 45-55.

IImi, Makhalul SM. 2002. Teori dan Praktek 
Aristina, et al/Jurnal Ekonomi Syariah Teori dan Terapan Vol. 6 No. 11 November 2019: 2198-2215; PERAN

PENYALURAN DANA PIHAK KETIGA BMT MUDA JATIM PADA PENINGKATAN KESEJAHTERRAAN PELAKU UMKM PERSPEKTIF MAQASHID SYARIAH

Lembaga Keuangan Mikro

Syariah.Yogyakarta: UII Press.

Karim, Adiwarman. 2001. Ekonomi Islam, Suatu Kajian Kontemporer. Jakarta: gema Insani

Mubyarto. 1995. Pengantar Ekonomi Pertanian. Jakarta : LP3ES

Muhammad.2000. Sistem dan Prosedur Operasional Bank Syariah. Yogyakarta : Ull Press

Mukhdis, Amat. 2013 . Sistematika dan Rancangan Penelitian. Malang: Universitas Negeri Malang.

Muslich, Achmad Wardi. 2010. Fiqh Muamalat. Jakarta: Amzah

Ramdansyah, Silalahi. 2013. Pengembangan Model Pendanaan UMKM Berdasarkan Persepsi UMKM, Jurnal Keuangan dan Bisnis. Volume 5, Nomor 1. Universitas Negeri Medan.

Rusyd, Ibnu. 1990. Bidayatul Mutjahid 3, terj. Semarang: Assyifa.

Sabiq, sayyid. 2004. Fiqhus Sunnah. Terjemahan Oleh Nor Hasanuddin. Jakarta: pena Pundi Aksara.

Sodiqin, Ali. 2012 Fiqh Usul Fiqh: Sejarah, Metodologi dan Implementasi di Indonesia. Yogyakarta: Berada Publishing

Soekanto, Soerjono. 1982. Sosiologi Suatu Pengantar. Jakarta : CV Rajawali Soemitra, Andri. 2009. Bank dan Lembaga
Keuangan Syariah.

Jakarta:Kencana

Sudarsono, Heri. 2007. Bank dan Lembaga Kevangan Syariah. Deskripsi dan Ilustrasi. Yogyakarta: Ekonisia FE UII.

Sudarman, Danim. 2003. Ekonomi Sumber Daya Manusia. Bandung: CV. Pustaka Setia

Suheny, Hendi.2002. Fiqh Muamalah. Jakarta: Raja Grafindo Persada.

Suwiknyo, Dwi. 2009. Kamus Lengkap Ekonomi Islam. Yogyakarta: Total Media.

Syarifuddin, Amir.2011. Usul Fiqh Jilid II. Jakarta Kencana

Tadjab. 1994. Perbandingan Pendidikan. Surabaya: Karya Abditama.

Todaro, Michael P. dan Stephen C. Smith. 2003. Pembangunan Ekonomi di Dunia ketiga, edisi kedelapan. Jakarta: Erlangga

Yin, Robert K. 2003. Studi Kasus : Desain Metode. Jakarta: Raja Grafindo Persada

Https://www.bi.go.id

Https://www.kompasiana.com

Http://www.bmtmuda.com/2012/01/profil e-bmt.html 